\title{
A Highest Purpose of Archaeology -Towards a Future Worthy of our Children
}

\author{
Fabio Carbone $e^{1,2 *}$ \\ ${ }^{1}$ Coventry University, Centre for Trust Peace and Social Relations, USA \\ ${ }^{2}$ Ambassador of Peace of the International institute for Peace through Tourism, New York, USA
}

Submission: August 31, 2018; Published: September 14, 2018

*Corresponding author: Fabio Carbone, Coventry University, Centre for Trust Peace and Social Relations, Ambassador of Peace of the International institute for Peace through Tourism, USA, Email: fabiocarbone.pro@gmail.com

\begin{abstract}
How could an archaeologist become ambassador of peace? This opinion paper collects some of the considerations underlying my academic works on the relationship between archeology and human development. After a relatively short period of excavations in Europe (some years), 1 have chosen to ask myself what could possibly be the meaning of the archaeological research and the value of the archaeological remains for the society, beyond the role traditionally attributed to archaeology. Such a question catapulted me in a journey, a lifelong project based on the belief that archeology - and cultural heritage in general - can effectively be one of the pillars of the so-called human development, and even vehicle of intercultural dialogue, global mutual understanding and peace. Perhaps, this can be considered one of the new skills of the archaeologists of the third millennium, that of linking dimensions apparently distant from that of archaeology, such as the policy of integration of migrants and refugees, the boost of intercultural skills for locals and visitors, the promotion of global mutual understanding and the creation of peace. And get ready to embrace the challenge of a higher purpose of archaeology.
\end{abstract}

Keywords: Theoretical Archaeology; Public archaeology; Cultural heritage management; Paideia approach; Human development; Peace building

\section{Introduction}

For any archaeologist worth the name, the context represents a fundamental source of information. So, let us start by defining the context that has represented the breeding ground for the opinions expressed in this paper. The typical reader of this scientific journal - thus many of those who will read this article - is aware of the existence of a city, in Italy, called Crotone. Not because they know something about this city in the current days,

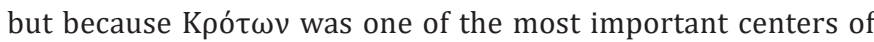
the ancient Magna Graecia. Greek settlers from the Achaia region founded this city in the second half of the eighth century BC, in the place of a pre-existing indigenous settlement, and their figures such as Pythagoras of Samos (4th-5th century BC) lived and worked. Here, this is where I was born. As a child, my father, a state employee with great love of history, used to bring me on the archaeological digs to watch the archaeologists at work on the latest discoveries. He used to explain me how important those discoveries were. However, despite my fascination with archaeology, I had a question that crept into me, and grew up with me and it grew up in parallel with my social awareness. "Is this stuff important... for who?"

Indeed, despite the numbers of important archaeological, geoarchaeological and geological sites, unfortunately the facts suggest that Crotone is facing in the last decades a continuous, relentless and in many ways dramatic socioeconomic and cultural decline. My question as a child therefore began to be better structured: "is it possible to establish a relationship between the presence of archaeological assets, their management, and the socioeconomic and cultural development of this place?" Over the years, then, I progressively realized that this same question could be formulated for several other places in the world and, in general, used as a starting point for a reflection on archaeology and cultural heritage management at global level. What was the question/intuition of a child, thus became my lifelong project, that of investigating the relationships between cultural heritage, its management and the actual and potential links with human development?

\section{Defining a Highest Purpose of Archaeology}

"Archaeology is partly the discovery of the treasures of the past, partly the meticulous work of the scientific analyst, partly the exercise of the creative imagination" [1]. This is what we use to learn about archaeology as students. Fascinating definition (quoting just one of them), but eventually something that did not answered my 10-years-old boy question! And this my "intellectual adventure", an "academic journey" in search of what can be called a highest purpose of archaeology.

If, on the one side, the application of complexity (and new technologies) to the investigation of contexts and landscapes led to the creation of new archaeological methods and branch - as the case of the geo-archaeology, which has its roots in the complex considerations of the Italian geologist Gioacchino Lena $[2,3]$ - on the other side, over the years, archaeologists 
have questioned themselves about the purpose of archeology. Archeology has indeed always reflected the culture of its time, of which it has differently interpreted needs and perspectives. Nevertheless, this has not always coincided with the formulation of a real "archaeological thought" [4]. The latter has been instead conquered by relatively new generations of archaeologists and it allowed investigating the theoretical aspects of the discipline. The first was the Finnish archaeologist Aarne Michaël Tallgren, in 1937. Most recently, among others, it is worth to mention Hodder [5] which, among other innovations within the theoretical archaeology, questions the role of archeology today, the themes of communication, language and archaeological writing. It has been thus open for decades a theoretical, epistemological debate (also with space for new and more complex approaches to the investigation, such as the geo-archaeological one outlined by But back to the paradigmatic perspective, just to mention relatively more recent milestones, the transition (or, eventually, reaction) from the American, neo-positivist New Archeology (or processual archaeology) to the Hodders's post-processual archaeology, according to which archaeology belongs to the social sciences [6-8]. On the one side, thus, post-processual approaches are characterized by new traits such as subjectivity of observations, cultural complexity, giving importance to the individual of any category in society (subaltern classes, women, marginalized, minorities) and promoting interdisciplinary links. Nevertheless, on the other side these elements represent almost exclusively an innovative direction of research and interpretation, namely about the active role of material culture in human relationships and social formation. In short, it seems clear that such a theoretical ferment concerns, above all, interpretative paradigms, even if in strict relations with highly topical matters (e.g. gender archaeology and the feminist movements), more than the reflection about the role of archaeology in our society, particularly in the context of current global socio-economic and cultural challenges.

My studies revealed, for instance, provide the empirical support to affirm the need to make archaeologists and cultural heritage managers more aware of the importance of public participation, often omitted or taken for granted within the archaeological research projects and cultural heritage management practices, if not in theory, however in practice $[9,10]$. Public participation is instead the basis of my proposals for a more current role of archeology in today's socio-cultural and economic challenges. The Paideia approach to cultural heritage management [11-13] for instance, emphasizes the importance of the pedagogical and social function of archaeology as a vehicle to strengthen local identities, on the one side, and intercultural capacities, on the other side. This proposal refers to the Socratic vision of human relations applied to archaeological research and cultural heritage management. Socrates sustained, at the dawn

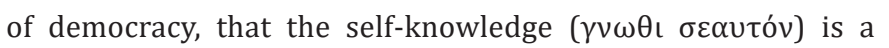
fundamental element (at individual as well as at collective level) to establish a constructive, peaceful dialogue with "the other(s)".

The responsibility of archaeologists and cultural heritage managers is thus not only that of recovery the past through this or that approach to the interpretation of its material remains, but also that of guarantee the greatest possible public participation by maximizing the sociocultural benefits of such engagement.

From the Archaeological Site to the Global Peace. the Archaeologist as Interface Between the Past and the Future

At the beginning of my work, the Socratic vision of the archaeological logos referred to the possible socio-cultural benefits of local communities, through a model strongly based on public participation and tourist activity as a promoter of intercultural dialogue [13]. However, the applicability of this model in the context of more complex scenarios has become increasingly evident, moving the potential impact of the Paideia approach from the local to the global level. In this sense I have talked about the potential benefits of the application of the Paideia approach to cultural heritage management to the effectiveness of the practice of cultural diplomacy in the field of international relations [14]. Moreover, I have also explored the possible links between archeology and the phenomenon of migration [15-17]. In this sense, reflecting the perspective of the Paideia approach to cultural heritage management, I believe that the role of cultural heritage should be emphasized not only within the process of the new comers' integration, but also as measure to overcome the identity crisis occurring in Western countries, among the main causes - in my opinion - of the crisis of multiculturalism. In this context, cultural heritage managers' new responsibilities are complex: on the one hand, to boost public participation in enhancing local heritage, on the other, to support migrants' cultures and the promotion of intercultural competencies within society. Archeology has the possibility to sensitize the communities on the. Opening a window on the past, telling about the human need to establish contacts among different groups to evolve, the archaeologist becomes a guiding light of navigation towards the future.

\section{Defining a Conditio Sine Qua Non}

For this dynamic ideal whose research and archaeological heritage can have real results, it is necessary to have preconditions. Among these, the need for such research and management practices to be specular at global level. The paideia approach mentioned above must be applied to the archaeological heritage and archaeological agenda at international level, involving the community of the whole global village. How, in practice, would it be possible to "standardize" this practice? Through a definition of quality in this respect should include not only technical aspects, but also the capacity to promote public participation to strengthen self-esteem, on the one hand, and intercultural skills, on the other $[18,19]$. Another important necessary condition would be the revision of the curricula for archeology students. Communication, management, leadership, archeology and globalization would be among the subjects that should appear alongside the more traditional "archaeological excavation methodologies", "stratigraphy", "conservation" and 
so on. Future archaeologists will thus have the duty but also the practical and theoretical means to establish a new agenda for archaeological research and the management of cultural heritage, not alien to the surrounding world and to society, not limited to reconstructing and narrating history, but rather to involve the public in the reconstruction of values and meanings.

\section{Conclusion}

The idea of a highest purpose of archaeology represents a theoretical proposal related to the role of archaeology today and its challenges. Why archaeologists should talk about the future human development and peace? Which kind of contribution they should provide to promote and support a global mutual understanding? The social liquidity described by Bauman seems to have relegated us to a new socio-cultural Middle Age that is undermining the basis for a sustainable human development and for global understanding and peace. In this context, archaeology can and should be the fulcrum for a new renaissance, acting in an integrated way, as a primus inter pares among human and social sciences. Archaeology can be witness of the human need to open to the other as an antechamber of social evolution. What is the positive peace, at local, national and global level, if not a journey of knowledge, education and encounter? In this journey, archaeology can act as an instrument of dialogue, mediation between different cultures and peace.

Embracing this complex challenge will involve the review of many theoretical and practical aspects of archaeology, from the agenda and practices of research to those of cultural heritage management. It will then necessary to strategically integrate the archaeological agenda with the sectors such as those of education, economics (including tourist activity, as a promoter of global mobility thus encounter among cultures). It will be necessary to define standard of quality among the archaeological heritage management referring to the Paideia approach to cultural heritage management. It will be necessary to training the new generation of archaeologists and cultural heritage managers to get ready to embrace a highest purpose of archaeology. Let start by raising awareness about the fact that our responsibility is not only the discovery, interpretation and communication of the past, but also the active engagement in the foundation of a future worthy of our children.

\section{References}

1. Renfrew C, Bahn P (2012) Archaeology. Theories, Methods and Practice ( $6^{\text {th }}$ edn.), Thames \& Hudson, London, UK.

2. Lena G (1996) Geo archeologia: nuova frontiera applicativa per le scienze della terra. Geologia dell'Ambiente 4: 5-9.
3. Lena G (2014) Alcune riflessioni sul lavoro del geoarcheologo. Geologia dell'Ambiente XXII (2): 107-111.

4. Trigger B (1989) A history of archaeological thought. Cambridge University Press, Cambridge, UK.

5. Hodder I (1999) The archaeological process. An introduction: Blackwell, Oxford, UK.

6. Hodder I (1982) Symbolic and Structural Archaeology. Cambridge University Press, Cambridge, UK.

7. Hodder I (1984) Burials, houses, men and women in the European Neolithic. In: Tilley MA (Eds.), Ideology, Power and Prehistory. Cambridge University Press, Cambridge, UK, p. 51-68.

8. Hodder I, Hutson S (2003) Reading the Past: Current Approaches to Interpretation in Archaeology ( $3^{\text {rd }}$ edn.). Cambridge University Press, Cambridge, UK.

9. Carbone F (2016a) Cultural Heritage Quality Management: Analysis of archaeological heritage managers' perception. European Journal of Tourism Research, 14: 114-118.

10. Carbone F (2016b) An insight into cultural heritage quality management of tourism sites. European Journal of Tourism Research, 14: 75-91.

11. Carbone F, Oosterbeek L, Costa C (2012) The educational and awareness purposes of the Paideia approach for heritage management. Natural Hazards and Earth System Sciences 12: 1983-1986.

12. Carbone F, Oosterbeek L, Costa C (2013) Paideia Approach for heritage management, The tourist enhancement of archaeological heritage on behalf of local communities. Pasos - Journal of Tourism and Cultural Heritage 2(2): 285-295.

13. Carbone F, Oosterbeek L, Costa C (2012) Paideia approach: bridging tourism and community development based on heritage enhancement. RT\&D - Journal of Tourism and Development, 17(18): 165-166.

14. Carbone F (2017) International Tourism and Cultural Diplomacy: A new conceptual approach towards global mutual understanding and peace through tourism. Tourism. An International Interdisciplinary Journal, 65(1): 61-74.

15. Carbone F (2018) Post-multicultural challenges for cultural heritage managers and museums in the age of migrations. Museum Management and Curatorship p.1-22.

16. Cuozzo, M, Guidi A (2013) Archeologia delle identita' e delle differenze. Carocci, Roma, Italy.

17. Oosterbeek L (2008) Gestão da arqueologia: mudar o paparadigma! Praxis Archaeologica, 3: 139-144.

18. Oosterbeek L (2015) Revisitando Antígona: O Património Cultural Na Fronteira da Globalização. In: Juliano Bitencourt Campos, Daniel Ribeiro Preve, Souza IFD (Eds.), Patrimônio cultural, direito e meio ambiente. Um debate sobre a globalização, cidadania e sustentabilidade, Multideia, Curitiba, Brazil.

19. Oosterbeek L, Pollicen F (2014) Cultural Heritage and Local Development. Local communities through heritage awareness and global understanding. Territori della Culture p. 18. 
(i) This work is licensed under Creative Commons Attribution 4.0 License DOI:_10.19080/GJAA.2018.06.555693

\section{Your next submission with Juniper Publishers} will reach you the below assets

- Quality Editorial service

- Swift Peer Review

- Reprints availability

- E-prints Service

- Manuscript Podcast for convenient understanding

- Global attainment for your research

- Manuscript accessibility in different formats ( Pdf, E-pub, Full Text, Audio)

- Unceasing customer service

Track the below URL for one-step submission https://juniperpublishers.com/online-submission.php 